\title{
Floristic composition of established vegetation and the soil seed bank in pasture communities under different traditional management regimes
}

\author{
A. López-Mariño ${ }^{\text {a,* }}$, E. Luis-Calabuig ${ }^{\text {a }}$, F. Fillat $^{\mathrm{b}}$, F.F. Bermúdez $^{\mathrm{c}}$ \\ ${ }^{a}$ Area de Ecología, Facultad de Biología, Universidad de León, 24071, León, Spain \\ ${ }^{\mathrm{b}}$ Instituto Pirenaico de Ecología (CSIC), Apdo 64, 22700 Jaca, Huesca, Spain \\ ${ }^{c}$ Estación Agrícola Experimental (CSIC), Apdo 788, 24080 León, Spain
}

Received 24 August 1998; received in revised form 23 July 1999; accepted 1 October 1999

\begin{abstract}
The floristic composition of the established vegetation and the soil seed bank in seven herbaceous communities under different traditional management regimes were compared in the Valdeón valley (Picos de Europa, Spain), a valley chosen for study because of its high diversity and non-dominance of any single species which have become increasingly rare in Western Europe as a result of changes in agriculture practices. Although the biological richness in this valley is well know, few studies have been made of the effects of different traditional management regimes on the floristic soil seed bank composition of these grasslands. The aim of this study was to examine the influence of traditional management regimes on the floristic composition of the established vegetation and soil seed bank determining which species groups are most represented in each case to increase scientific information about these communities that every day are more scarce in Western Europe because of intensive management (generally due to fertiliser application to increase production) and abandonment of the traditional methods of management with a profound modification of the agrarian structure. An indirect germination method was used to study the seed bank. Soil samples were put into a germination chamber. 119 species of the vegetation and 104 of the seed bank were identified, 54 species being common to both. Results were analysed using Correspondence Analysis (CA), samples and species on the above-ground flora being ordered in the first two axes in well-defined groups: limestone and siliceous pastures, formerly-cultivated land and hay meadow. In the case of the below-ground seed bank, the manure used as fertiliser in some communities affected principally the concentration of therophytes in the soil and defined the different groups. Sampling time, management and differences between the persistence of seeds of different species in the soil seed bank were responsible for the large differences between the composition of the vegetation and seed bank. Ruderal species, species with persistent seeds and therophytes, which were better represented in the seed bank were responsible for the low correlation between seed bank and vegetation established. (2000 Elsevier Science B.V. All rights reserved.
\end{abstract}

Keywords: Traditional management; Correspondence analysis; Germination chamber; Pastures; Seed bank; Floristic composition; Spain

\section{Introduction}

Hay meadows are becoming increasingly scarce in North Europe because of the very intensive management and because of abandonment of land (Bakker

${ }^{*}$ Corresponding author. Fax: +349-8729-1501. E-mail address: deglcg@unileon.es (A. López-Mariño). et al., 1980; Willems, 1983; Goldsmith, 1986). The 
importance of protecting these areas and conserving their high diversity is well recognised (Smith, 1985). Traditional, extensive management methods have been used for generations in the Valdeón valley (NE Leon, Spain), and have contributed to the creation of highly diverse plant communities, which can be observed at plot and landscape scales (García, 1992).

The soil seed bank plays an important role in the composition of different plant communities and thus in their conservation (Grubb, 1977; Leck et al., 1989; Wisheu and Keddy, 1991). The composition of the seed bank depends on the production and composition of the present and previous plant communities, as well as on the longevity of the seeds of each species under local conditions. If there is a disturbance to the plant community, the seed bank may intervene in re-establishing the original community. This relationship between the composition of the seed bank and the vegetation is particularly important for the vegetation that appears under different management regimes (Fredrickson and Taylor, 1982).

It is well known that the seed bank is unlikely to be important in recreating species-rich grassland, and the seed rain from adjacent areas is probably more important (Graham and Hutching, 1988a, b; Hutchings and Booth, 1996).

The aim of the present study was to examine the influence of traditional management regimes on the floristic composition, both of the established vegetation and of the soil seed bank in the different plant communities under different traditional management regimes, determining which species groups are most represented in each case to increase scientific information about these communities characterised by their high diversity and every day more scarce in Western Europe because of intensive management.

\section{Materials and methods}

Seven pasture plant communities were selected along the length of the Valdeón valley in the North-East of the province of León, which falls within the limits of the Picos de Europa National Park. The area was chosen because all sites were managed under different traditional regimes leading to the creation of high-diversity plant communities.
Three communities (C1, C2 and C3) are located in the lower altitude and are the most intensively managed through addition of animal manure and cut for hay (C1 and C2). Communities C4, C5, C6 and C7 are located at higher altitude and are subjected to less intensive management, one cut for hay or no cut and no added manure. All communities are grazed (Table 1).

The vegetation of this zone is characterised by the presence of beech woods (Fagus sylvatica) occupying $12 \%$ of the valley surface. Three percent of the area is occupied by mixed woods of beech and oaks (Quercus petraea, Quercus pyrenaica, Quercus faginea), ash trees, hazels and holly, among others. The rest of the vegetation of the valley comprises heather, scrub, hay meadows and limestone and siliceous pastures (García, 1992). The climate is continental with an atlantic influence, but varies considerably within the valley as a function of orientation and altitude. Temperature averages $9.3^{\circ} \mathrm{C}$ with an annual rainfall at $900 \mathrm{~m}$ of $1783 \mathrm{~mm}$.

Manure collected from the enclosures used to house cattle in winter, is used as fertiliser in spring. The use of chemical fertilisers is very rare in this area. Pastures are manually cut using a scythe, usually at the end of June in the case of the lower pastures to the end of July for the higher pastures.

Samples of seed bank were taken in March 1994 with a hoe because of stony soil was finding it impossible to use the cores. Soil samples were from two depths, $0-10 \mathrm{~cm}$ and $10-20 \mathrm{~cm}$. In the first three communities (C1, C2 and C3), 100 samples were taken (50 from each depth), whereas in C4, C5, C6 and C7, the number of samples was halved because of the size of the pasture or the shorter herbage.

In the laboratory, each sample was divided into two parts, making groups of 10 (without mixing the samples from different management regimes nor depths). This was done to achieve a greater degree of homogeneity and representativity of all samples. Finally, 20 samples were obtained (10 from each depth) for $\mathrm{C} 1$, C2 and C3, and 10 (5 from each depth) for C4, C5, C6 and C7. Subsamples of $400 \mathrm{~cm}^{3}$ were taken from each sample and these were used for germination tests. Thus, a total of $8000 \mathrm{~cm}^{3}$ were sampled from each of the first three communities and $4000 \mathrm{~cm}^{3}$ from each of the other four.

Indirect germination in a controlled environment was used to study the soil seed bank. A germination 
Table 1

Characteristics of the herbaceous communities studied in the Valdeón valley

\begin{tabular}{|c|c|c|c|c|}
\hline Community & Management regime & Altitude (m) & $\mathrm{pH}$ & Gradient $\left(^{\circ}\right)$ \\
\hline $\mathrm{C} 1$ & $\begin{array}{l}2 \text { cuts (annual) } \\
\text { Alfalfa stopped being sown } 7 \text { or } 8 \text { years ago } \\
\text { Manured (annual) } \\
\text { Grazed in autumn }\end{array}$ & 900 & 7.3 & 0 \\
\hline $\mathrm{C} 2$ & $\begin{array}{l}\text { Near to dung heap } \\
\text { Grazed in spring and autumn (annual) }\end{array}$ & 830 & 7.5 & $0-10$ \\
\hline $\mathrm{C} 3$ & $\begin{array}{l}1 \text { or } 2 \text { cuts (depending on the year) } \\
\text { Manured only occasionally (annual) } \\
\text { Grazed in autumn }\end{array}$ & 900 & 6.5 & $>10$ \\
\hline $\mathrm{C} 4$ & $\begin{array}{l}1 \text { cut (annual) } \\
\text { Not manured } \\
\text { Grazed in autumn }\end{array}$ & 1300 & 5.8 & $>10$ \\
\hline $\mathrm{C} 5$ & $\begin{array}{l}1 \text { cut (some years only) } \\
\text { Not manured } \\
\text { Grazed in spring and autumn (depending on the year) }\end{array}$ & 1300 & 5.1 & $>10$ \\
\hline C6 & $\begin{array}{l}\text { Abandoned hay meadows (has mown } 10-15 \text { years ago) } \\
\text { Not manured } \\
\text { Grazed in spring and autumn }\end{array}$ & 1300 & 5.4 & $>10$ \\
\hline $\mathrm{C} 7$ & $\begin{array}{l}\text { Beech clearing } \\
\text { Not manured } \\
\text { Grazed in spring and autumn }\end{array}$ & 1450 & 4.3 & 0 \\
\hline
\end{tabular}

chamber, programmed for $14 \mathrm{~h}$ of light and $25^{\circ} \mathrm{C}$ and $68 \%$ humidity and $10 \mathrm{~h}$ of darkness at $15^{\circ} \mathrm{C}$ and a $80 \%$ humidity was employed. Two different methodologies were used for comparative purposes and also to achieve the greatest possible number of germinations. Half of the samples were not concentrated by washing but after a first germination underwent a stress period without light or humidity (NCS method), the other samples were concentrated by washing and then sprayed with gibberelic acid in order to favour the seed germination in the latency phase ( $\mathrm{CG}$ method) (López-Mariño, 1997).

Identification and counting of seedling were done using keys of cotyledons and first true leaves (Davies, 1959; Chancellor, 1964; Buendía, 1966; Ruiz del Castillo, 1970; Muller, 1978; Chancellor, 1983; Hanf, 1983; Villarias, 1986). Some grasses and Cyperacea were identified by leaf cuticle keys (García-González, 1983; Aldezabal and García-González, 1992). Some Juncus spp. were determined using keys of their transversal section structures and of longitudinal epidermal sections (Fernández-Carvajal, 1982). The most difficult species to identify by this method were transplanted into pots for adult identification.
In June 1995 vegetation was sampled from the seven communities using a $1 \mathrm{~m}^{2}$ quadrat thrown at random 10 times onto the surface of the pasture. Frequency data were collected from within the quadrant.

The species making up the vegetation and the soil seed bank were classified in three different ways:

1. According to the biological form following the biotypical and symorphical classification of Raunkiaer (Mueller-Dombois and Ellenberg, 1974) in phanerophytes, camephytes, geophytes, hemicryptophytes and therophytes.

2. Agronomic groups according to the supply of nutrients to the pastures. These were classified into grasses, legumes and 'other families' (Roberts, 1981; Rice, 1989). Furthermore, a new group was considered for classification, ruderal species, which were those from environments created for human occupation and their associated buildings. One of the features of this environment as far as the soil is concerned is the high nitrogen content. Thus, many of the species considered to constitute ruderal flora are so-called nitrophilous.

3. Taking into account the type of seed bank according to the classification of Thompson and Grime 
(1979), species being classified as Types I, II, III or IV.

Nomenclature follows the Flora Iberica (Vols. I-IV) (Castroviejo, 1986-1993) and Flora Europea (Tutin et al., 1964-1980).

Correspondence analysis (CA) was used to analyse data statistically, using the programme package SYN-TAX-PC (Podani, 1993). For established vegetation, qualitative data of presence-absence of species was used, and data on species abundance to a depth of $20 \mathrm{~cm}$ was used for the soil seed bank. Kendall's correlation index (Siegel and Castellan, 1988) was used to compare the frequency of species in the established vegetation with that in the seed bank, testing the correlation between them.

\section{Results and discussion}

A total of 169 taxa were present among the species making up the established vegetation and those in the seed bank. In the established vegetation of the seven communities studied, a total of 119 different species were identified of which 25 were grasses, 12 were legumes, 74 were classified in the 'other families' group and 8 were ruderal species. Of the 119 species, only 54 ( $45 \%$ of the total) were also found in the soil seed bank of some of the communities studied ( 7 grasses, 8 legumes, 33 from 'other families' and 6 ruderal species). The difference in composition between above-ground flora and below-ground seed bank of pastures has been confirmed by similar Spanish studies (Reiné and Chocarro, 1994 of communities in the central Pyrenees; Ortega, 1994 of pastures in the Guadarrama mountain range).

From the $40,000 \mathrm{~cm}^{3}$ of soil samples left to germinate in the germination chamber, a total of 2326 seeds germinated. Of these, 72 died before they could be identified, leaving 2254 seeds which were identified into 104 different species. Of these 10 were grasses, 8 legumes, 57 from 'other families' and 29 ruderal species.

Of all the germinated seeds, 1677 seeds were found at the first depth and 649 (28\% of the total) at the second. Furthermore, 1130 seeds of all those which germinated were from the samples treated by NCS method (non-concentrating samples and just after the stress period) and 1196 were from CG method (con- centrated samples by washing and subsequent use of gibberelic acid).

The species which were only present in the established vegetation and not represented in the seed bank of any of the communities samples, had a predominantly transitory type of bank (Types I or II) and the most abundant biological form was the hemicryptophyte. In contrast the species found only in the seed banks were predominantly of the persistent type (Types III or IV), the biological form being the therophyte.

The taxa found in both the vegetation and in the seed bank had mostly a persistent type of bank (Types III and IV) with the hemicryptophyte biological form.

In all the above mentioned cases, the agronomic group 'other families' was the most abundant.

Figs. 1 and 2 show the ordination of the samples and species obtained from the CA for the established vegetation and the soil seed bank, respectively.

In both cases the samples were located in the plane formed by the two axes, in well-defined groups, such as the limestone and siliceous pastures which were well differentiated ( $\mathrm{C} 2$ and $\mathrm{C} 7)$, as was the formerly-cultivated land (C1) and the group of hay meadows (C3, C4 and C5). Pasture $\mathrm{C} 3$ which is situated at a lower altitude and is managed more intensively, being manured and mown (twice some years), is clearly separate from the other three $(\mathrm{C} 4, \mathrm{C} 5$ and C6).

In a study carried out by Chocarro et al. (1989), five pastures under different management regimes in the Valdeón valley were sampled. Ordination analysis clearly separated the pastures under intensive management from those with a less intensive management. As in the present study, the results of Chocarro et al. (1989) did not show a clear separation of pastures at higher altitudes $(1300 \mathrm{~m})$, even though they had different management regimes.

The higher values on axis 1, both for the established vegetation (Fig. 1) and for the soil seed bank (Fig. 2) were from the pasture $\mathrm{C}$, whereas samples from pasture $\mathrm{C} 1$ were located in the most negative portion of this axis.

The greatest difference in the position of samples between the established vegetation and the seed bank were found in community C2. Samples of the soil seed bank (Fig. 2) were situated towards the most negative portion of the axis, because of the effect of manure 


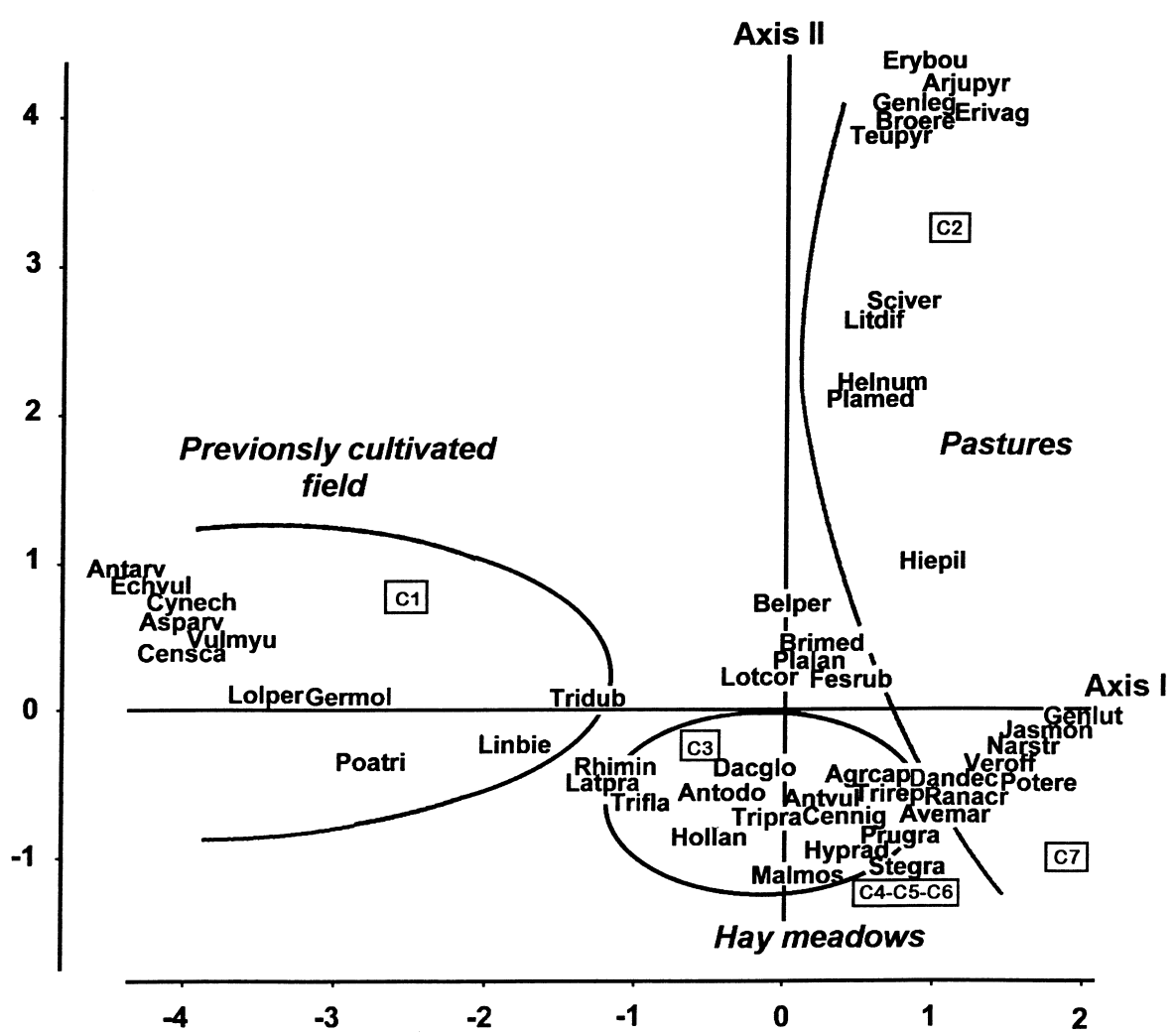

Fig. 1. Correspondence analysis of the vegetation established (ordination the samples and species. Taxa were represented by three letters of the genus and three of the species).

deposited near the area, making nitrophilous ruderal species or species common to cultivated lands such as Chenopodium album, Sonchus asper, or Anthemis arvensis appear, these being uncharacteristic of limestone pastures. The result is an ordination in sharp contrast to that of the established vegetation characterised by species native to limestone pastures, such as Genista legionensis, Erica vagans or Ajuga pyramidalis (Fig. 1). Organic fertilisers contain a large number of seeds of field and ruderal species (Mcdonald et al., 1996) and livestock disperse seeds of pasture species through their dung (Malo and Suárez, 1995).

When the order of species in the first two axes for the established vegetation (Fig. 1) is examined, the species typical of pastures and pasture-scrub were located towards the most positive extreme of axis 1, with species such as Gentiana lutea, Nardus stricta, Avenula marginata, Exica vagans, Hieracium pilosella, Helianthemum nummularium and Festuca rubra. In contrast, ruderal species and species typical of abandoned cultivated land are situated towards the negative portion of this axis, e.g. Anthemis arvensis, Echium vulgaris or Vulpia myurus. Between these two extremes are found those species typical of hay meadows, such as Linum bienne, Trifolium dubium, Astrantia major, Rhinanthus minor and Dactylis glomerata.

Fig. 2 show this same tendency, species from the seed bank show the order of the species in the same plane formed by these two first axes. Species such as Aphanes arvensis, Erodium cicutarium, Urtica dioica, Chenopodium album, Anthemis arvensis, Arenaria serpyllifolia, Echium vulgare or Medicago lupulina are situated at the most negative part of axis 1, whereas in the most positive part, where the samples from pasture $\mathrm{C} 7$ are located, typical pasture species such as Hieracium pilosella and Sagina saginoides are found. 


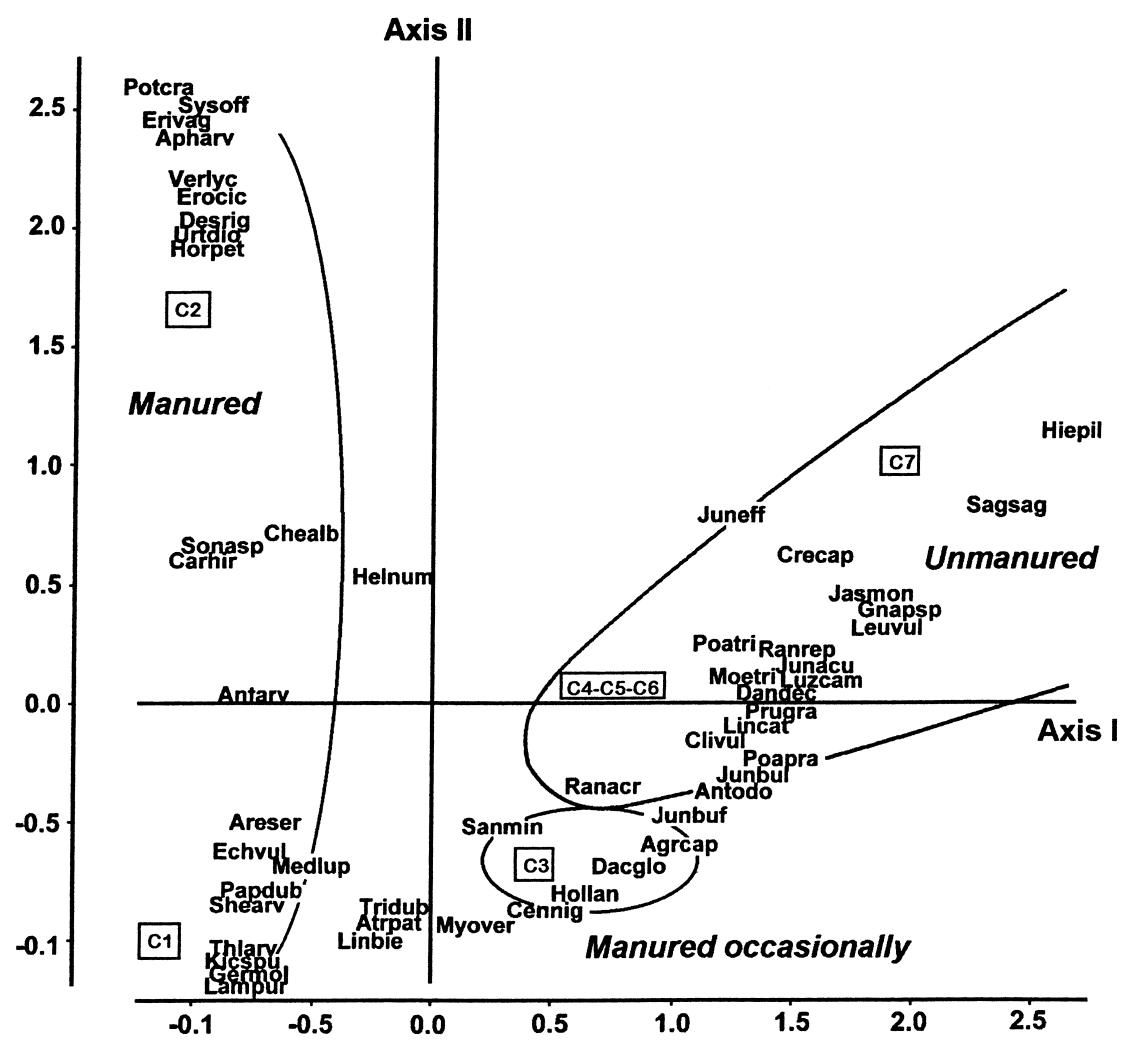

Fig. 2. Correspondence analysis of the soil seed bank (ordination the samples and species. Taxa were represented by three letters of the genus and three of the species).

In axis 1 , for both analyses, a gradient of management intensity can be appreciated, with the most ruderal and nitrophilous species situated towards the most negative part, followed by species typical of hay meadows and, subsequently, species typical of pastures in the most positive portion. In a study by García (1992) on the importance of conserving the richness of plant species in Europe, a components analysis was performed using the percentage cover data for the floristic composition of five meadows in the Valdeon valley, the intensity of management in each being different. The graphical representation of the analysis allowed a clear separation to be seen between those meadows which were organically fertilised and those which were not. The fertilisation regime is closely related to the intensity of management in this area and to the proximity of the meadows to urban centres, those situated at lower altitudes being more intensively managed.
In the case of the soil seed bank (Fig. 2), the management intensity affected principally the concentration of therophytes in the soil. The meadows receiving manure, which provides many seeds, and the formerly cultivated land were located at the most negative portion of axis 1 .

For the established vegetation (Fig. 1), the most positive portion of axis II is occupied by species such as Erica vagans, Teucrium pyrenaicum and Ajuga pyramidalis, typical of limestone pastures, and in the more negative portion, hay meadow species such as Malva moschata, Dactylis glomerata and Rhinanthus minor as well as species typical of high altitude meadows such as Gentiana lutea.

The significance of this second axis is not very clear, perhaps because of the 'arc' effect characteristic of classical CA (Hill, 1974), although from the order of samples, an altitude gradient can be appreciated which 


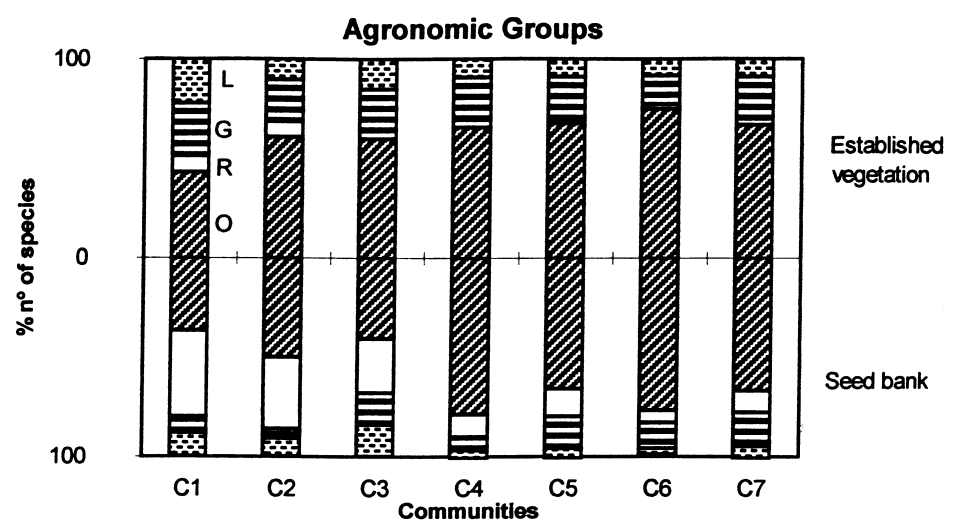

Fig. 3. Percentage number of species in vegetation and soil seed bank $(0-20 \mathrm{~cm})$ for different managements classified according to agronomy group (O: Other families; R: Ruderal species; G: Grasses; L: Leguminous).

in the study area corresponds to the different $\mathrm{pH}$ of the substrates.

Fig. 2 (the soil seed bank) shows that it is the samples from pasture $\mathrm{C} 2$, which are now situated towards the positive portion of axis II. The species situated at the positive portion of the axis are characteristic of limestone and siliceous pastures, such as Erica vagans, Potentilla crantzii, Hornungia petraea, Hieracium pilosella and Sagina saginoides. In the most negative portion of axis II are ruderal species such as Lamium purpureum, Geranium molle, Thlaspi arvense and species typical of meadows, such as Linum bienne, Trifolium dubium, Holcus lanatus and Dactylis glomerata. Taking this ordering into account, axis II reflects the different management regimes used on the different meadows. Species favoured by the mowing of hay meadows are situated towards the more negative portion of the axis in contrast to the location of the pasture species.

In order to clarify the characteristics of the species groups which contributed to the different location of the samples and species in the graphical representation of the CA, the graphs of percentage number of species between vegetation and seed bank classified on the basis of agronomic group (Fig. 3), type of bank formed by the seeds (Fig. 4) and the biological form (Fig. 5) were compared. Ruderal species gained importance in the seed bank, especially in the first three meadows, even outweighing in importance, that of the other families in $\mathrm{C} 1$. The trend in the different groups is similar for all management regimes, an increase in the ruderal species group and a decrease in the grasses

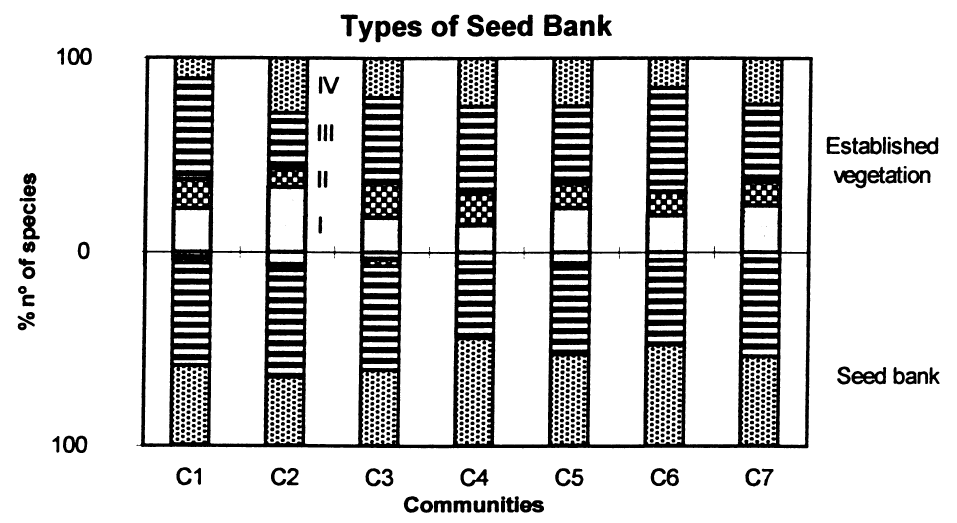

Fig. 4. Percentage number of species in vegetation and soil seed bank $(0-20 \mathrm{~cm})$ for different managements classified according to seed bank type. 


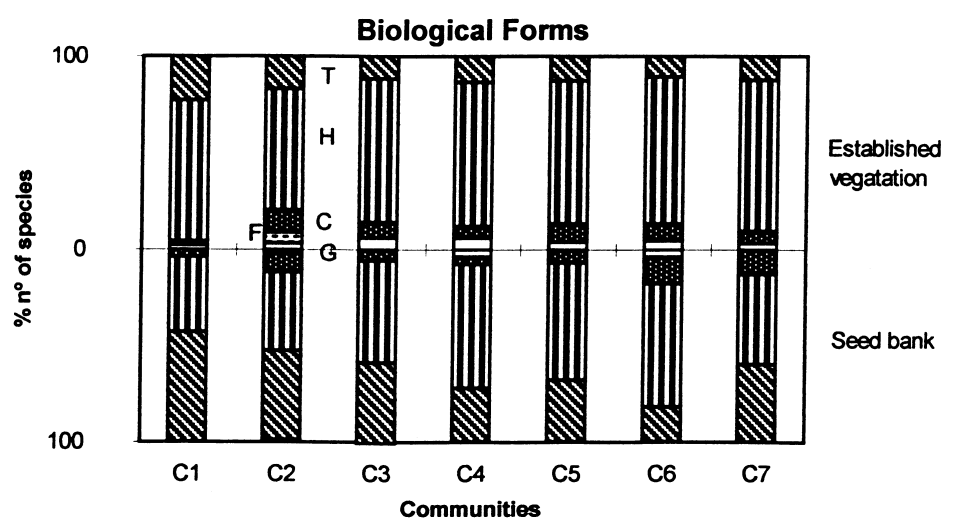

Fig. 5. Percentage number of species in vegetation and soil seed bank $(0-20 \mathrm{~cm})$ for different managements classified according to biological forms (T: Therophytes; H: Hemicryptophytes; C: Chamaephytes; G: Geophytes; F: Phanerophytes).

and legumes of the seed bank in comparison with the established vegetation.

As far as classifying species according to the type of seed bank is concerned and comparing the percentages between the established and potential vegetation, there is a general tendency to a greater number of species with types III and IV in the bank (predominantly of the persistent type) compared with the vegetation, and a lower number of types I and II (predominantly transitory type of bank; Fig. 4).

Finally, comparing vegetation and seed bank for percentage number of species classified by biological form for the different communities (Fig. 5), the importance acquired by the therophytes in the seed bank as compared with the established vegetation is obvious in all communities, but especially in the lower altitude more intensely managed ones. Reiné and Chocarro (1994), in a study of a meadow community in the central Pyrenees which was cut twice for hay and grazed twice per year, found therophytes to be present mainly in the seed bank, with almost all the established vegetation species being hemicryptophytes.

These great differences between the floristic composition found by studying the soil seed bank (taking into account the total depth from 0 to $20 \mathrm{~cm}$ ) and the established vegetation, were quantified using Kendall's correlation index (Table 2).

In all cases there was a negative correlation which was significant for all meadows except $\mathrm{C} 5$ and was the greatest for $\mathrm{C} 2$ and $\mathrm{C} 4$. This indicates that the frequency trends for the different species making up the
Table 2

Kendall correlation indices and significance level between floristic composition and soil seed bank frequency ${ }^{\mathrm{a}}$

\begin{tabular}{llll}
\hline Management & \multicolumn{3}{l}{ Established vegetation-seed bank $(0-20 \mathrm{~cm})$} \\
\cline { 2 - 4 } & $N$ & Kendall Tau $\left(r_{\mathrm{k}}\right)$ & Significance level \\
\hline C1 & 81 & -0.31 & $* * *$ \\
C2 & 71 & -0.43 & $* * *$ \\
C3 & 70 & -0.18 & $*$ \\
C4 & 68 & -0.43 & $* * *$ \\
C5 & 75 & -0.15 & n.s. \\
C6 & 65 & -0.28 & $* * *$ \\
C7 & 44 & -0.24 & $* *$
\end{tabular}

${ }^{\mathrm{a}} N$ : species number each management; $r_{\mathrm{k}}$ : Kendall correlation index; $* p<0.05 ; * * p<0.01 ; * * * p<0.001$; n.s.: not significant.

established vegetation and potential vegetation vary in opposite directions. García Morchón (1995) also found significant correlations for some pastures in the Aragonese Pyrenees.

The richness of the vegetation should be related to that of the seed bank, although the abundance of some taxa varies as a function of their reproductive strategies. Annual species may be present with a greater frequency in the bank than in the established vegetation because of their capacity for producing persistent seeds, with the perennial species being better represented in the established vegetation than in the seed bank because of asexual reproduction (Ortega, 1994).

The difference in composition between the established vegetation and the seed bank in these ecosystems has been amply confirmed by many authors 
(Chippindale and Milton, 1934; Major and Pyott, 1966; Hayashi and Numata, 1968; Thompson, 1986; Reiné and Chocarro, 1994).

In the present study the reason for the similarity between the composition of the established vegetation and that of the potential vegetation should be short, owing to time of sampling of the seed bank. The time of sampling of soil for the study of the seed bank is an important factor influencing the results obtained (Roberts, 1981; Recasens et al., 1991). In winter the majority of seeds in the samples of soil are persistent. Thus, the species with transitory seeds (especially type I) are not found in the soil seed bank at this time. This especially affects species of grasses because these have a greater number of seeds of this type. Thus, species such as Arrhenatherum elatius, Bromus sterilis, Cynosorus cristatus, Lolium perenne, Festuca rubra, Briza media, Bromus erectus and Phleum pratense among others are only present in the established vegetation and normally at high frequencies.

In contrast, in $\mathrm{C} 1$ and $\mathrm{C} 2$ there are species in the seed bank which are absent from the established vegetation as a result of an old crop which previously occupied the fields or from the presence of manure. Species such as Arenaria serpyllifolia, Sherardia arvensis, Fallopia convolvulus or Polygonum bellardii among others are only found in the soil seed bank. Milberg (1992) points out how the survival of seeds from weed species contributes to the lack of correspondence between the established vegetation and the soil seed bank. Douglas (1965) maintains that the presence of seeds in the meadow soil arises from the fact that these seeds were previously cultivated when the land was under a different management regime, and that these germinated forming part of the established vegetation. With the change of management the seeds remain in store in the seed bank and decrease in number over time and lose their viability (Chippindale and Milton, 1934).

In the higher altitude communities subjected to less intensive management, Juncus species that were represented with a high frequency in the bank were absent from the established vegetation. This frequent by occurs in studies of soil seed banks (Williams, 1984; Thompson, 1986) and is the main cause of the lack of correspondence between the established vegetation and the potential vegetation of the bank in communities located at higher altitude and with higher humidity.

\section{Acknowledgements}

This work has been performed as part of project CE AIR3-CT92-0079.

\section{References}

Aldezabal, A., García-González, R., 1992. Clave para la determinación de las graminoides más abundantes de los pastos supraforestales del Pirineo Occidental a partir de sus epidermis foliares. In: Actas de la XXXII Reunión Científica de la S.E.E.P., Pamplona, pp 37-44.

Bakker, J.P., Dekker, M., De Vries, Y., 1980. The effect of different management practices on a grassland community and the resulting fate of seedlings. Acta Bot. Neerl. 29 (5/6), 469482.

Buendía, F., 1966. Semillas y plántulas de leguminosas pratenses españolas. Ministerio de Agricultura. Madrid.

Castroviejo, S., Aedo, C., Cirujano, S., Laínz, M., Montserrat, P., Morales, R., Muñoz-Garmendia, F., Navarro, C., Paiva, J., Soriano, C., 1986-1993. Flora Ibérica: plantas vasculares de la Península Ibérica y Baleares. Vols. 1-4. Real Jardín Botánico, CSIC, Madrid.

Chancellor, R.J., 1964. Identificación de Plántulas de Malas Hierbas, Ed. Acribia, Zaragoza.

Chancellor, R.J., 1983. The identification of weed seedlings of farm and garden. Blackwell scientific publications, Oxford.

Chippindale, H.G., Milton, W.E.J., 1934. On the viable seeds present in the soil beneath pastures. J. Ecol. 22, 508-531.

Chocarro, C., Fanlo, R., Fillat, F., García, A., Navascués, I., 1989. Comparación entre dos métodos de muestreo en prados de siega en los montes Cantábricos y el Pirineo Central español. Principales resultados, Acta Biol. Mont., Vol. 9, pp. 291-300.

Davies, I., 1959. The use of epidermal characteristics for the identification of grasses in the leafy stage. J. Br. Grassland Soc. 14 (1), 7-16.

Douglas, G., 1965. The weed flora of chemically-renewed lowland swards. J. Br. Grassland Soc. 20, 91-100.

Fernández-Carvajal, M.C., 1982. Revisión del género Juncus II. Anales Jardín Botánico de Madrid 38(2).

Fredrickson, L.H., Taylor, T.S., 1982. In: Management of Seasonally Flooded Impoundments for Wildlife. Resour. Publ. 148. U.S. Fish Wildl. Serv., Washington, DC.

García Morchón, P., 1995. El banco de semillas en comunidades herbáceas de ladera en el Pirineo Aragonés (Fragen, valle de Broto). Trabajo final de carrera. Escuela Universitaria Politécnica de Huesca, Universidad de Zaragoza.

García, A., 1992. Conserving the species-rich meadows of Europe. Agric., Ecosys. Environ. 40, 219-232. 
García-González, R., 1983. Epidermis foliares de algunas especies de Festuca, Poa y Bellardiochloa en el Pirineo Occidental. Anales del Jardín Botánico de Madrid 39 (2), 389-404.

Goldsmith, F.B. (Ed.), 1986. The hay meadows of the Picos de Europa. Discussion Papers in Conservation, Vol. 43, University College, London.

Graham, D.J., Hutching, M.J., 1988a. Estimation of the seed bank of a chalk grassland ley established on former arable land. J. Appl. Ecol. 25, 241-252.

Graham, D.J., Hutching, M.J., 1988b. A field investigation of germination from the seed bank of a chalk grassland ley on former arable land. J. Appl. Ecol. 25, 253-263.

Grubb, P.J., 1977. The maintenance of species-richness in plant communities: the importance of the regeneration niche. Biol. Rev. 52, 107-145.

Hanf, M., 1983. The Arable Weeds of Europe with their Seedlings and Seeds. BASF, UK.

Hayashi, I., Numata, M., 1968. Ecology of pioneer species of early stages in secondary succession II. The seed production. Bot. Mag. Tokyo 81, 55-66.

Hill, M.O., 1974. Correspondence analysis: a neglected multivariate method. Appl. Statist. 23, 340-354.

Hutchings, M.J., Booth, K.D., 1996. Studies on the feasibility of re-creating chalk grassland vegetation on ex-arable land I. The potencial roles of the seed bank and the seed rain. J. Appl. Ecol. 33, 1171-1181.

Leck, M.A. Parker,Y.T., Simpson, R.L. (Eds.), 1989. Ecology of Soil Seed Banks. Academic Press, New York.

López-Mariño, A., 1997. Estudio del banco de semillas del suelo en prados y pastos del valle de Valdeón (Picos de Europa). Influencia del manejo tradicional y comparación entre dos métodos indirectos de germinación bajo ambiente controlado, Tesis Doctoral, Facultad de Biología, Universidad de León.

Major, J., Pyott, W.T., 1966. Buried viable seeds in two California bunchgrass sites and their bearing on the definition of a flora. Vegetatio 13, 253-282.

Malo, J.E., Suárez, F., 1995. La dispersión de semillas por el ganado a través de sus excrementos. Quercus, Octubre, pp. 34-37.

Mcdonald, A.W., Bakker, J.P., Vegelin, K., 1996. Seed bank classification and its importance for the restoration of species-rich flood-meadows. J. Vegetation Sci. 7, 157-164.

Milberg, P., 1992. Seed bank in a 35-year-old experiment with different treatments of a semi-natural grassland. Acta Oecol. 13 (6), 743-752.

Mueller-Dombois, D., Ellenberg, H., 1974. Aims and Methods of Vegetation Ecology. Wiley, New York.

Muller, F.M., 1978. Seedling of the North-western European lowland (a flora of seedling). Dr. W. Junk B.V. publishers,
The Hague, The Netherlands, Boston, U.S.A. and Centre for agricultural publishing and documentation, Wageningen, The Netherlands.

Ortega, M. 1994. Papel de los bancos de semillas en pastizales Mediterráneos: Variabilidad espacio-temporal y respuestas al abandono del pastoreo. Tesis doctoral, Facultad de Ciencias, Universidad Autónoma de Madrid.

Podani, J., 1993. SYN-TAX-pc. Computer Programs for Multivariate Date Analysis in Ecology and Systematics. Versión 5.0, Scientia Publishig, Budapest.

Recasens, J., Riba, F., Izquierdo, J., Taberner, A., 1991. L'anàlisi del banc de llavors de males herbes de sòls agrícoles. Aspectes Metodològics Llerda 'Ciènces' 49, 83-102.

Reiné, R., Chocarro, C., 1994. Relación entre el banco de semillas del suelo y la vegetación aérea en una comunidad pratense del Pirineo Central. In: Actas XXXIV Reunión Científica de la S.E.E.P., Santander, pp. 125-130.

Rice, K.J., 1989. Impacts of seed banks on grassland community structure population dynamics. In: Leck, M.A., Parker, Y.T., Simpson, R.L. (Eds.), Ecology of Seed Bank, Academic Press, New York.

Roberts, H.A., 1981. Seed banks in soils. Adv. Appl. Biol. 6, $1-55$.

Ruiz del Castillo, J., 1970. Semillas y plántulas de gramíneas pascícolas españolas. Ministerio de Agricultura, Madrid.

Siegel, S., Castellan, N.J., 1988. Nonparametric statistics (for the Behavioral Sciences), Mcgraw-Hill International Editions.

Smith, R.S., 1985. Conservation of Northern Upland Meadows. Yorkshire Dales National Park Committee.

Thompson, K., Grime, J.P., 1979. Seasonal variation in the seed banks of herbaceous species in ten contrasting habitats. J. Ecol. 67, 893-921.

Thompson, K., 1986. Small-scale heterogeneity in the seed bank of an acidic grassland. J. Ecol. 74, 733-738.

Tutin, T.G., Heywood, V.H., Burges, N.A., Moore, D.M., Valentine, D.H., Walters, S.M., Webb, D.A., 1964-1980. Flora Europaea. Vols. 1-5, Cambridge University Press, Cambridge.

Villarias, J.L., 1986. Atlas de malas hierbas. Ed. Mundi-Prensa, Madrid.

Willems, J.H., 1983. Species composition and above ground phytomass in chalk grassland with different management. Vegetatio 52, 171-180.

Williams, E.D., 1984. Changes during 3 years in the size and composition of the seed bank beneath a long-term pasture as influenced by defoliation and fertilizer regime. J. Appl. Ecol. 21, 603-615.

Wisheu, I.C., Keddy, P.A., 1991. Seed banks of a rare wetland plant community: distribution patterns and effects of human-induced disturbance. J. Vegetation Sci. 2, 181-188. 